\title{
Medicinal used plants from India: analysis of the essential oil of air-dried Biophytum sensitivum (L.) DC.
}

\author{
Leopold Jirovetz ${ }^{* 1}$, Gerhard Buchbauer ${ }^{1}$, Andrea Wobus ${ }^{1}$, Mohamed P. \\ Shafi ${ }^{2}$, Beena Jose ${ }^{2}$ \\ ${ }^{1}$ Department of Pharmaceutical Chemistry, University of Vienna, Althanstrasse \\ 14, A-1090 Vienna, Austria \\ ${ }^{2}$ Department of Chemistry, Calicut University, Kerala 673635 , India
}

\begin{abstract}
The essential oil of the air-dried plant Biophytum sensitivum (L.) DC. (Oxalidaceae) from Southern India was investigated by gas chromatographicspectroscopic (GC-FID and GC-MS) and olfactoric methods to identify compounds responsible for the characteristic odor as well as partly for the folk medicinal use of this plant. Especially benzene derivatives, such as 1,4dimethoxy benzene (24.9\%), 1,2-dimethoxy benzene (10.6\%) and 2-methoxy4-methyl phenol $(3.5 \%)$, the monoterpenes $(Z)$-linalool oxide $(8.1 \%),(E)$ linalool oxide $(5.2 \%)$ and linalyl acetate $(3.4 \%)$ as well as 1 -octen-3-ol $(9.5 \%)$ and isophorone $(3.1 \%)$ were found to be main constituents (concentrations higher than $3 \%$, calculated as relative \%-peak area of GC-FID analysis using an apolar column) of this essential oil, with totally 69 compounds identified. In addition, the odor impression of the sample is described and the possible biological activity of single volatiles discussed.
\end{abstract}

\section{Key Word Index}

Biophytum sensitivum (L.) DC., Oxalidaceae, essential oil, air-dried plant, Indian folk medicine 


\section{Introduction}

Biophytum sensitivum (L.) DC. belongs to the Oxalidaceae family (about 70 species known), native to the tropical areas of South Asia and Africa. $B$. sensitivum is an annual herb and used in traditional medicine of especially India, Indo-China, the Malaya Archipelago, Madagascar and Africa for its effects against convulsions, inflammatory tumors, burns, fevers, insomnia, asthma, phthisis and diabetes [1-11]. While various solvent extracts were studied for biological active compounds (mainly flavonoids) by many research teams [4-11], to the best of our knowledge, the essential oil constituents of $B$. sensitivum air-dried plants from southern India could be analyzed for the first time.

In continuation of our scientific work on the analyses of essential oils used in traditional Indian medicine, the aim also of this research project was to identify the volatiles of this essential oil of Biophytum sensitivum and to discuss the constituents responsible for the characteristic aroma impressions, their possible biological effects as well as applications in food-flavoring, perfumery and cosmetics.

\section{Results and discussion}

The essential oil of air-dried Biophytum sensitivum plants from Southern India was olfactorically evaluated as follows: spicy (direction of clove and fennel), earthy-woody (direction of mushrooms and cedarwood), tobacco- and leather-like, floral (direction of bergamote and lavender), fatty-fruity (hazelnutand coconut-notes) and sweet-creamy (vanilla-note).

Using gas chromatographic - spectroscopic systems 69 components could be identified (see Table 1). As main compounds (concentrations higher than $3 \%$, calculated as \%-peak-area of GC-FID analyses) of this sample especially benzene derivatives, such as 1,4-dimethoxy benzene (,hydroquinone dimethyl ether", 24.9\%), 1,2-dimethoxy benzene („pyrocatechol dimethyl ether", "veratrole", 10.6\%) and 2-methoxy-4-methyl phenol („2-methoxy-p-cresol", $3.5 \%)$, the monoterpenes $(Z)$-linalool oxide $(8.1 \%),(E)$-linalool oxide $(5.2 \%)$ 
and linalyl acetate $(3.4 \%)$ as well as 1 -octen-3-ol $(9.5 \%)$ and isophorone $(3.1 \%)$ were found.

\begin{tabular}{|c|c|c|}
\hline Compounds $^{1}$ & $e^{2}$ & $\mathrm{KI}^{3}$ \\
\hline 3-methyl butanol & $\operatorname{tr}^{4}$ & 733 \\
\hline 2-methyl butanol & $\operatorname{tr}$ & 737 \\
\hline hexanal & 0.1 & 778 \\
\hline (E)-2-hexenal & $\operatorname{tr}$ & 831 \\
\hline (Z)-3-hexenol & 0.1 & 845 \\
\hline$(E)$-2-hexenol & $\operatorname{tr}$ & 854 \\
\hline anisole & 0.5 & 917 \\
\hline$\alpha$-thujene & $\operatorname{tr}$ & 929 \\
\hline$\alpha$-pinene & 0.1 & 951 \\
\hline camphene & 0.1 & 953 \\
\hline$\beta$-pinene & 0.1 & 957 \\
\hline 1-octen-3-ol & 9.5 & 964 \\
\hline sabinene & $\operatorname{tr}$ & 975 \\
\hline 6-methy-5-hepten-2-ol & 2.5 & 992 \\
\hline octanal & $\operatorname{tr}$ & 1001 \\
\hline para-cymene & 0.1 & 1012 \\
\hline limonene & 0.1 & 1023 \\
\hline B-phellandrene & $\operatorname{tr}$ & 1028 \\
\hline 1,8-cineole & 0.1 & 1030 \\
\hline (E)-linalool oxide (furanoi) & 5.2 & 1061 \\
\hline (Z)-linalool oxide (furanoid) & 8.1 & 1064 \\
\hline 1-nonen-3-ol & $\operatorname{tr}$ & 1068 \\
\hline linalool & 1.9 & 1085 \\
\hline nonanal & $\operatorname{tr}$ & 1087 \\
\hline B-phenylethyl alcohol & $\operatorname{tr}$ & 1107 \\
\hline isophorone & 3.1 & 1121 \\
\hline 4-ketoisophorone & 1.6 & 1143 \\
\hline camphor & 0.6 & 1146 \\
\hline (Z)-3-nonen-1-ol & 1.7 & 1156 \\
\hline 1,2-dimethoxy benzene & 10.6 & 1168 \\
\hline (Z)-linalool oxide (pyranoid) & 2.3 & 1171 \\
\hline terpinen-4-ol & 1.6 & 1174 \\
\hline menthol & 0.1 & 1176 \\
\hline 1,3-dimethoxy benzene & 0.2 & 1178 \\
\hline$\alpha$-terpineol & 1.3 & 1185 \\
\hline
\end{tabular}




\begin{tabular}{|lcr|}
\hline 2-methoxy-4-methyl phenol & 3.5 & 1187 \\
\hline 1,4-dimethoxy benzene & 24.9 & 1191 \\
\hline safranal & 0.4 & 1197 \\
\hline decanal & 0.2 & 1206 \\
\hline geraniol & $\operatorname{tr}$ & 1253 \\
\hline linalyl acetate & 3.4 & 1258 \\
\hline decanol & 0.7 & 1269 \\
\hline para-menth-1-en-7-al & 1.2 & 1276 \\
\hline safrole & 0.6 & 1285 \\
\hline thymol & 1.3 & 1289 \\
\hline carvacrol & 0.3 & 1298 \\
\hline eugenol & 2.1 & 1358 \\
\hline dihydro eugenol & 0.3 & 1369 \\
\hline 1,1 -dimethoxy decane & 2.3 & 1379 \\
\hline$\alpha$-copaene & $\operatorname{tr}$ & 1399 \\
\hline methyl eugenol & 0.4 & 1407 \\
\hline carvone hydrate & 2.4 & 1422 \\
\hline$\beta$-caryophyllene & $\operatorname{tr}$ & 1424 \\
\hline$\alpha$-ionone & 0.2 & 1429 \\
\hline (E)- $\beta$-farnesene & $\operatorname{tr}$ & 1448 \\
\hline isoeugenol & 0.4 & 1452 \\
\hline decanol & 0.7 & 1468 \\
\hline$\beta$-ionone & 1.0 & 1486 \\
\hline$\delta$-cadinene & $\operatorname{tr}$ & 1505 \\
\hline 6 -methyl- $\alpha$-ionone & 0.2 & 1522 \\
\hline eugenyl acetate & 0.3 & 1524 \\
\hline (Z)-nerolidol & 0.3 & 1536 \\
\hline$(E)$-nerolidol & 0.2 & 1551 \\
\hline dimethyl ionone & 0.1 & 1566 \\
\hline caryophyllene oxide & $\operatorname{tr}$ & 1574 \\
\hline -cadinol & 0.8 & 1649 \\
\hline$(E, E)$-farnesol & 1733 \\
\hline phytol & 2080 \\
\hline
\end{tabular}

${ }^{1}$ in order of their elution

${ }^{2}$ concentrations as \%-peak-area caiculated by GC-FID analysis

${ }^{3}$ Kovats indices from apolar FSOT-RSL column

${ }^{4}$ not detected

${ }^{5}$ trace compound (less than $0.1 \%$ )

Tab. 1. Composition of the essential oil (eo) of air-dried plants of Biophytum sensitivum from Southern India 
The correlation of the olfactoric data with gas chromatographic - spectroscopic ones allows the following statement: Eugenol derivatives and 1,4-dimethoxy benzene are especially responsible for the spicy aroma impressions (direction of clove and fennel); earthy-woody odor notes are known from 1-octen-3-ol (mushroom-like), isophorone (cedarwood-like) and partly linalool oxides (,earthy-floral") and tobacco-and leather-like ones from isophorone and 2methoxy-4-methyl phenol. The floral aroma (direction of bergamote and lavender) can be attributed to linalool and its derivatives, such as ( $Z$ )- and (E)linalool oxide as well as linalyl acetate. 1,4-dimethoxy benzene, 1,2-dimethoxy benzene, 2-methoxy-4-methyl phenol, isophorone possess fatty-fruity and/or sweet-creamy odor notes and are therefore responsible for these aroma impressions of the Biophytum sensitivum sample [12-16].

Referring to the biological activities of identified constituents of the essential oil of air-dried plants of $B$. sensitivum from South-India the following report can be given: The identified phenolic compounds as well as linalool and its derivatives are known for their antimicrobial effects [17-21]. In addition, linalool and its derivatives should be mentioned for their mild sedative and spasmolytic activity [17-21]. Therefore, the essential oil of air-dried plants of Biophytum sensitivum from Southern India may be used as natural drug against convolusions, inflammatory tumors, burns, fevers and insomnia as reported elsewhere for $B$. sensitivum extracts [2-6].

A possible use of some main compounds with sweet-creamy-fatty (vanilla-, coconut- and hazelnut-notes), like 1,2-dimethoxy benzene, isophorone and 2methoxy-4-methyl phenol in food flavouring (candies, non-alcoholic beverages and bakeries [15]) is also remarkable, but needs a previous testing of nontoxicity.

For an application of the Biophytum sensitivum sample in perfumery and cometics the complex aroma impression could be of interest for products with some of the odor notes to include (earthy-woody and/or tobacco-leather-like and/or sweet-creamy-fatty), such as deodorants, soaps, perfumes and lotions of any type. 
In summary, the essential oil of air-dried plants of Biophytum sensitivum from South-India possess a characteristic pleasant odor, showing benzene derivatives (1,4-dimethoxy benzene, 1,2-dimethoxy benzene and 2-methoxy-4methyl phenol), monoterpenes (linalyl acetate, (Z)- and (E)-linalool oxide), 1octen-3-ol and isophorone as main compounds. These constituents are especially responsible for the complex odor impression, a possible use as natural drug against different diseases, for the flavoring of various foods as well as aroma-intense agents in some perfumery and cosmetic products.

\section{Experimental}

\section{Plant Material}

The fresh plants $(250 \mathrm{~g})$ of Biophytum sensitivum were collected from the Calicut University campus (Paddy field) in August 2002 and the plant material identified by Dr.A.K. Pradeep, Department of Botany, Calicut University of Kerala. A voucher specimen is deposited in the specially maintained Herbarium of the Department of Chemistry at Calicut University (voucher-no. 41). The plants were air-dried for 1 month at room-temperature $\left(22^{\circ} \mathrm{C}\right)$ and powdered using an electric grinder.

\section{Essential Oil Extractions}

The air-dried and powdered $B$. sensitivum were steam-distilled using a Clevenger-apparatus for 2.0 hours. The essential oil was extracted with diethyl ether $(2 \times 100 \mathrm{~mL})$ as solvent and dried over anhydrous sodium sulphate. After removal of the sodium sulphate and evaporation of the ether a yield of $0.01 \mathrm{~g}$ $(0.004 \%)$ pale yellow-green essential oil was obtained.

\section{Olfactoric Evaluations}

The essential oils were diluted with dichloromethane, $10 \mu$ l placed on a commercial odor-strip and the odor characterized by professional perfumers. 


\section{Gas Chromatography}

GC analyses were carried out using a Shimadzu GC-14A with FID and the integrator C-R6A-Chromatopac and a Varian GC-3700 with FID and the integrator C-R1B-Chromatopac (Shimadzu Co.). As columns a $30 \mathrm{~m} \times 0.32 \mathrm{~mm}$ bonded unpolar FSOT-RSL-200 fused silica (film-thickness: $0.25 \mu \mathrm{m}$, Biorad Co.) and a $30 \mathrm{~m} \times 0.32 \mathrm{~mm}$ bonded polar Stabilwax (film-thickness: $0.50 \mu \mathrm{m}$; Restek Co.) were used. Additional parameters as follows: Carrier gas: hydrogen; injector-temperature: $250^{\circ} \mathrm{C}$; detector-temperature: $320^{\circ} \mathrm{C}$; temp.programs: $40^{\circ} \mathrm{C} / 5 \mathrm{~min}$. to $280^{\circ} \mathrm{C} / 5 \mathrm{~min}$. with a heating-rate of $6^{\circ} \mathrm{C} / \mathrm{min}$; ; quantifications by \%-peak-area-calculations (unpolar column);

Some single components could be identified by co-injection of pure compounds and correlation of their retention-times (using Kovats indices) with published data [22-25].

\section{Gas Chromatography - Mass Spectrometry}

The samples were analyzed by the GC-MS systems Shimadzu GC-17A with QP5000 and the data system Compaq-ProLinea (class5k-software), HewlettPackard GC-HP5890 with HP-5970MSD and PC-Pentium (Böhm Co., ChemStation-software) and Finnigan MAT GCQ with data system Gateway2000-PS75 (Siemens Co., GCQ-software). Additional parameters as follows: Carrier gas: helium; injector-temperature: $250^{\circ} \mathrm{C}$; interface-heating: $300^{\circ} \mathrm{C}$; ionsource-heating: $200^{\circ} \mathrm{C}$; El-mode; scan-range: 41-450amu; other parameters see GC-FID-part.

For compound identifications Wiley-, NBS- and NIST-library spectra (on-line) as well as reference MS-spectra data [24, 26-32] were used.

\section{Acknowledgements}

We acknowledge the olfactoric evaluations by Mr. W. Höppner and Mr. V. Hausmann, perfumers of Symrise (former Dragoco Co.), Vienna, Austria, the botanical identification of the plant material by Dr.A.K. Pradeep, Department of Botany, Calicut University Kerala, India, the junior research fellowship from the 
CSIR New Delhi (B. Jose) as well as the financial support (scholarship for A. Wobus) by the University of Vienna.

\section{References}

[1] Heywood V H, editor. Biophytum sensitivum. In: Blütenpflanzen der Welt. Basel:Birkhäuser-Verlag, 1982:209.

[2] Neuwinger H D, editor. Biophytum sensitivum. In: African Traditional Medicine. Stuttgart:medpharm Scientific Publishers, 2000:69.

[3] Parrotta J A, editor. Biophytum sensitivum. In: Healing Plants of Peninsular India. New York:CABI Publishing, 2001:557.

[4] Bucar F, Jachak S M, Kartnig T, Schubert-Zsilavecz M. Phenolic compounds from Biophytum sensitivum. Pharmazie 1998;53:6513.

[5] Bucar F, Jachak S M, Noreen Y, Kartnig T, Perera P, Bohlin L, SchubertZsilavecz M.

Amentoflavone from Biophytum sensitivum and its Effect on COX-1/COX-2 Catalyzed Prostaglandin Biosynthesis.

Planta Med. 1998;64:373-4.

[6] Jachak S M, Bucar F, Kartnig T.

Antiinflammatory activity of extracts of Biophytum sensitivum in carrageenin-induced rat paw oedema. Phytother. Res. 1999;13:73-4.

[7] Lin Y L, Wang W Y.

Chemical constituents of Biophytum sensitivum.

Chinese Pharm. J. 2003;55:71-5.

[8] Paul S, Bhowmik G, Baruah P, Roy M K.

A novel report on non-legume module system in Biophytum sensitivum. J. Assam Sci. Soc. 1995;37:185-7.

[9] Puri D, Baral N.

Hypoclycemic effect of Biophytum sensitivum in the alloxan diabetic rabbits. Indian J. Physiol. Pharmacol. 1998;42:401-6.

[10] Puri D.

The insulintropic activity of a Nepalese medicinal plant Biophytum sensitivum: preliminary experimental study.

J. Ethnopharmacol. 2001;78:89-93.

[11] Ravishankara M N, Pillai A D, Padh H, Rajani M. A sensitive HPTLC method for estimation of amentoflavone, a bioactive principle from Biophytum sensitivum (Linn.) DC. and Putranjiva roxburghii Wall.. 
J. Planar Chromatogr. 2003;16:201-5.

[12] Arctander S, editor.

Perfume and Flavor Chemicals.

Montclair:Published by the author, 1969.

[13] Bauer K, Garbe D., Surburg, H.

Common Fragrance and Flavor Material.

Weinheim:VCH-Verlagsges.m.b.H., 1997.

[14] Fazzalari F A.

Compilation of Odor and Taste Threshold Values Data.

Philadelphia:American Society for Testing and Materials, Data Series 48d, 1978.

[15] Furia T E, Bellanca N, editors.

Fenaroli's Handbook of Flavour Ingredients.

Cleveland:CRC Press, 1975.

[16] Sigma-Aldrich.

Flavors \& Fragrances, The Essence of Excellence.

Milwaukee:Sigma-Aldrich Co., 2001.

[17] Buchbauer G, Jäger W, Jirovetz L, Ilmberger J, Dietrich H.

Therapeutic Properties of Essential Oils and Fragrances.

In: Bioactive Volatile Compounds from Plants, ACS-Symposium-Series 525 , 159-65.

Washington:American Chemical Society, 1993.

[18] Buchbauer G, Jirovetz L, Jäger W, Plank C, Dietrich $H$.

Fragrance Compounds and Essential Oils with Sedative Effects upon Inhalation.

J. Pharm. Sci. 1993;82:660-4.

[19] Buchbauer G, Jirovetz L.

Aromatherapy - Use of Fragrances and Essential Oils as Medicaments.

Flavour Fragr. J. 1994;9:217-22.

[20] Jirovetz L, Buchbauer G, Fleischhacker W, Ngassoum M B, Yonkeu S.

Analysis of the Essential Oil of Stems and Leaves of Diplolophium

africanum Turcz. from Cameroon.

Acta Pharm. Turcica 1998;40:185-8.

[21] Jirovetz L, Buchbauer G, Fleischhacker W.

Analysis of the Essential Oil of the Leaves of the Medicinal Plant

Chenopodium ambrosioides var. anthelminticum (L.) A. Gray from India.

Sci. Pharm. 2000;68:123-8.

[22] Davies N W.

Gas chromatographic retention indices of monoterpenes and

sesquiterpenes on methyl silicone and Carbowax 20M phases.

J. Chromatogr. 1990;503:1-24.

[23] Jennings $W$, Shibamoto $T$.

Qualitative Analysis of Flavor and Fragrance Volatiles by Glass Capillary

Gas Chromatography.

New York:Academic Press, 1980.

[24] Jirovetz L.

Private retention-time listings.

[25] Kondjoyan N, Berdaque J L. 
A Compilation of Relative Retention Indices for the Analysis of Aromatic Compounds.

Saint Genes Champanelle:Edition du Laboratoire Flaveur, 1996.

[26] Adams R P.

Identification of essential oil components by gas chromatography /

quadrupole mass spectroscopy.

Carol Stream:Allured Publishing Corp., 2001.

[27] Cornu A, Massot R.

Compilation of Mass Spectral Data, Vol. 1-2.

London:Heyden \& Sons, 1975.

[28] Jirovetz L.

Private mass spectra libraries.

[29] Joulain D, König W A.

The Atlas of Spectral Data of Sesquiterpene Hydrocarbons.

Hamburg: E.B.-Verlag, 1998.

[30] McLafferty F W, Staufer D B.

The Wiley NBS Registry of Mass Spectral Data, Vol. II.

New York:John Wiley, 1989.

[31] Pfleger K, Maurer H H, Weber A.

Mass Spectral and GC Data of Drugs, Poisons, Pesticides, Pollutants and Their Metabolites.

Weinheim:WILEY-VCH, 2000.

[32] Stenhagen E, Abrahamsson S, McLafferty F W.

Registry of Mass Spectral Data, Vol. 1-4.

New York:John Wiley, 1974. 